\title{
Correlated variation of chromosomal inversion (3R)C and extra bristles in Drosophila melanogaster
}

\author{
J. I. IZOUIERDO, E. GARCÍA-VÁZOUEZ \& B. VILLAR \\ Departamento de Biologia Funcional, Area de Genética, Universidad de Oviedo, 33071-Oviedo, Spain
}

\begin{abstract}
Chromosomal inversion $\operatorname{In}(3 \mathrm{R}) \mathrm{C}$ and extra dorsocentral and scutellar macrochaetae are correlated in Asturian natural populations of Drosophila melanogaster in that selection for extra bristles produced an increase in $\operatorname{In}(3 \mathrm{R}) \mathrm{C}$ frequency. In the present work two populations with significantly different frequencies of the $\operatorname{In}(3 \mathrm{R}) \mathrm{C}$ inversion were created and a significant positive correlation between $\operatorname{In}(3 R) C$ frequency and frequency of individuals carrying extra bristles was found. This result confirms the correlation between bristles and $\operatorname{In}(3 \mathrm{R}) \mathrm{C}$. In addition, the correlation between the two characters is also demonstrated at the individual level.
\end{abstract}

Keywords: chromosomal inversion, correlation $\operatorname{In}(3 \mathrm{R})$ C-E.B., extra bristles, Drosophila melanogaster, $\operatorname{In}(3 \mathrm{R}) \mathrm{C}$.

\section{Introduction}

Correlation between chromosomal inversions and different characters is said by some workers to be the main force that accounts for the maintenance of some inversion polymorphisms in wild and domesticated populations of Drosophila melanogaster (e.g. Afonso et al., 1985). Other authors explain inversion polymorphisms by a selective advantage of heterokaryotypes (e.g. Laurie-Ahlberg \& Merrell, 1979; Barnes, 1983). Finally, some authors propose that supergenic selection maintains inversion polymorphisms because of co-adaptation (e.g. Watanabe \& Yamazaki, 1976; García-Vázquez \& Sánchez-Refusta, 1989).

Polygenes that determine extra bristles are on all the major chromosomes in $D$. melanogaster with variable influence depending on the lines (Sheldon \& Milton, 1972; García-Vázquez \& Rubio, 1988). Rubio \& Albornoz (1982) found a zone in the $3 R$ arm that determines a significant increase in the bristle number that overlaps more than 50 per cent with the $\operatorname{In}(3 \mathrm{R}) \mathrm{C}$.

Chromosomal inversion $\operatorname{In}(3 \mathrm{R}) \mathrm{C}$ and extra macrochaetae were found in Asturian natural populations in variable frequencies that can be very high (GarciaVázquez et al., 1989). In these populations a correlation between the variation of dorsocentral and scutellar bristles and the frequency of $\operatorname{In}(3 \mathrm{R}) \mathrm{C}$ was discovered. García-Vázquez \& Sánchez-Refusta (1989) demonstrated that by selecting recently caught lines for increasing bristle number, $\operatorname{In}(3 \mathrm{R}) \mathrm{C}$ heterozygote frequency also increased. The higher the response to selection for bristles, the higher the frequency of $\operatorname{In}(3 \mathrm{R}) \mathrm{C}$ maintained in such lines.

In this paper, we test the inverse phenomenon: in recently caught lines managed with respect to their $\operatorname{In}(3 R) C$ frequency, the occurrence of extra bristles is shown to be correlated with different $\operatorname{In}(3 R) C$ frequencies. In addition, we also investigate the existence of the correlation at the individual level, in an attempt to determine its biological significance.

\section{Materials and methods}

A sample of 56 Drosophila melanogaster females was captured in a cellar of Asturias (North of Spain), using yeasted banana traps. Isofemale lines, each from the progeny of one female, were established in the laboratory.

Salivary gland chromosomes from five larvae per line were analysed in the first laboratory generation, according to Levine \& Schwartz's (1970) method. Chromosomal pattern was determined by direct analysis, using Lefèvre's (1976) standard photographic map.

To start the INV population, five virgin couples were selected from each of the 10 isofemale lines showing the highest frequency of the cosmopolitan inversion $\operatorname{In}(3 R) C$. To start the STD population, the same 
procedure was followed with the 10 isofemale lines showing the highest frequency of standard chromosomes.

The chromosomal patterns of 50 first-generation larvae from each of the newly created STD and INV populations were analysed by the same method described above. We also recorded in this generation the phenotypes of dorsocentral and scutellar macrochaetae of 500 males and 500 females from each population. Flies with fewer bristles than the normal phenotype appeared in negligible proportions (less than 0.5 per cent) and are not considered in our results.

In this generation, 50 virgin females from the INV population were crossed with 50 virgin males from the STD population to create the INV $\times$ STD population. The same procedure was followed with 50 females from STD and 50 males from INV to create the STD $\times$ INV one. Chromosomal arrangements and extra bristles were recorded in the first generation of these populations, following the procedure described for INV and STD.

The INV and STD populations were maintained separately in 10 bottles each, with standard culture medium. Six generations without artificial selection were obtained by means of rotational crosses. Inversions were recorded in 30 larvae per population in each of generations G.1, G.3, G.4 and G.6. Bristles were recorded in 500 males and 500 females at G.6, in both populations.

In parallel to these experiments, two lines were started from each of STD and INV populations using 10 couples per line. Selection for increasing number of dorsocentral and scutellar bristles was performed in the four STD-1, STD-2, INV-1 and INV-2 lines. The 10 females and 10 males with the best phenotype (having at least one extra bristle) were selected from each generation. From the first to the fifteenth generation the extra bristle phenotype of 50 females and 50 males, taken at random, were registered in each of the four lines.

In the fifteenth generation, bristle phenotypes were registered in 50 virgin females from STD-1 and in 47 virgin females from INV-1. These females were then individually mated to males from the Canton strain, a strain standard for chromosome constitution. By analysing five larvae in the offspring of each female, we deduced (with a confidence level of 95 per cent) the chromosomic arrangement of the female $(\mathrm{St} / \mathrm{St}$, $\mathrm{St} / 3 \mathrm{RC}$ or $3 \mathrm{RC} / 3 \mathrm{RC}$ ).

Individual correlations between the number of extra bristles and the number of chromosome arms with $\operatorname{In}(3 \mathrm{R}) \mathrm{C}$ were then tested in the females from each of the STD- 1 and INV- 1 lines.

\section{Results}

Inversion frequencies in the captured population were 8.03 per cent for $\operatorname{In}(2 \mathrm{~L}) \mathrm{t}, 7.14$ per cent for $\operatorname{In}(2 \mathrm{R}) \mathrm{NS}$, 1.78 per cent for $\operatorname{In}(3 \mathrm{~L}) \mathrm{P}, 0.89$ per cent for $\operatorname{In}(3 \mathrm{R}) \mathrm{P}$ and 15.18 per cent for $\operatorname{In}(3 \mathrm{R}) \mathrm{C}$.

Table 1 shows the frequencies of $\operatorname{In}(3 R) C$ in the newly created populations: STD, INV, STD $\times$ INV and $\mathrm{INV} \times \mathrm{STD}$. The frequencies of $\operatorname{In}(3 \mathrm{R}) \mathrm{C}$ in STD and in INV populations differed significantly in a contingency chi-square test $\left(\chi_{1}^{2}=89.66 ; P<0.001\right)$ in the initial generation (G.0.) but there was no significant difference for any other investigated inversions. On the contrary, $\operatorname{In}(3 \mathrm{R}) \mathrm{C}$ frequencies from the STD $\times$ INV and INV $\times$ STD populations did not differ $\left(\chi_{1}^{2}=0.134\right)$ : no maternal effect on inversions is evident.

Transforming frequencies in Table 1 by the expression $\arcsin \sqrt{p}$ ( $p$ being the frequency), a positive significant correlation $(r=0.970 ; P<0.05)$ was revealed between the percentage of chromosome arms carrying $\operatorname{In}(3 \mathrm{R}) \mathrm{C}$ and the percentage of individuals with extra bristles.

After six generations without artificial selection, $\operatorname{In}(3 \mathrm{R}) \mathrm{C}$ frequency decreased slightly in the INV population and increased slightly in the STD population, while the percentage of individuals with extra bristles was maintained in both populations (Table 2). We can see that the correlation between $\operatorname{In}(3 \mathrm{R}) \mathrm{C}$ and extra bristles did not change in the laboratory, at least in the first generations.

Table 1 Frequencies (in per cent) of chromosome arms with the inversion $(3 \mathrm{R}) \mathrm{C}(\mathrm{IN})$ and individuals carrying extra bristles (EB), in the four analysed populations

\begin{tabular}{lrc}
\hline Population & \multicolumn{1}{c}{ IN } & EB \\
\hline INV & 71.00 & 8.2 \\
STD & 5.00 & 3.8 \\
INV $\times$ STD & 56.66 & 8.6 \\
STD $\times$ INV & 51.66 & 7.6 \\
\hline
\end{tabular}

Table 2 Frequency (in per cent) of chromosome arms with the inversion $(3 \mathrm{R}) \mathrm{C}$ in the analysed generations and per cent of individuals carrying extra bristles (EB) at the sixth generation

\begin{tabular}{lrrrrrr}
\hline \multicolumn{7}{c}{ Generations } \\
\cline { 2 - 7 } Population & G.0 & G.1 & G.3 & G.4 & G.6 & EB \\
\hline INV & 71.0 & 70.0 & 67.5 & 65.0 & 60.0 & 9 \\
STD & 5.0 & 5.0 & 5.0 & 5.0 & 10.0 & 3 \\
\hline
\end{tabular}


Table 3 Average of extra bristles per female or male for 15 generations of selection in the four lines STD-1, STD-2, INV-1 and INV-2, regression coefficients $(b)$ and their significance in a Student's $t$-test

\begin{tabular}{|c|c|c|c|c|c|c|c|c|}
\hline \multirow[b]{2}{*}{ Generations } & \multicolumn{2}{|l|}{ STD-1 } & \multicolumn{2}{|l|}{ STD-2 } & \multicolumn{2}{|l|}{ INV-1 } & \multicolumn{2}{|l|}{ INV-2 } \\
\hline & \% & $0^{\prime \prime}$ & q & 0 & q & 0 & \% & 0 \\
\hline G.0 & 0.068 & 0.012 & 0.068 & 0.012 & 0.114 & 0.034 & 0.114 & 0.034 \\
\hline G.1 & 0.12 & 0.00 & 0.32 & 0.02 & 0.62 & 0.02 & 0.30 & 0.06 \\
\hline G. 2 & 0.00 & 0.00 & 0.22 & 0.04 & 1.16 & 1.04 & 0.48 & 0.16 \\
\hline G.3 & 0.10 & 0.02 & 0.40 & 0.19 & 2.18 & 0.94 & 1.04 & 0.56 \\
\hline G.4 & 0.20 & 0.02 & 0.42 & 0.20 & 2.44 & 0.72 & 2.42 & 0.60 \\
\hline G.5 & 0.06 & 0.10 & 0.72 & 0.40 & 2.46 & 1.30 & 1.94 & 1.10 \\
\hline G.6 & 0.30 & 0.10 & 1.10 & 0.68 & 3.06 & 2.00 & 2.22 & 1.50 \\
\hline G.7 & 0.24 & 0.18 & 1.26 & 0.66 & 3.52 & 2.40 & 2.72 & 2.16 \\
\hline G.8 & 0.20 & 0.20 & 1.20 & 0.42 & 2.58 & 1.86 & 2.22 & 1.72 \\
\hline G.9 & 0.62 & 0.28 & 1.32 & 0.78 & 3.70 & 2.64 & 3.00 & 2.42 \\
\hline G. 10 & 0.74 & 0.32 & 1.62 & 1.16 & 3.52 & 2.86 & 3.60 & 2.66 \\
\hline G.11 & 0.92 & 0.64 & 1.50 & 0.58 & 3.90 & 2.80 & 3.84 & 2.86 \\
\hline G.12 & 1.04 & 0.90 & 1.34 & 0.66 & 3.68 & 3.02 & 3.32 & 2.18 \\
\hline G.13 & 1.24 & 0.80 & 0.52 & 0.34 & 5.18 & 3.48 & 4.08 & 2.44 \\
\hline G.14 & 1.46 & 0.96 & 0.70 & 0.24 & 4.50 & 2.68 & 4.10 & 3.16 \\
\hline \multirow[t]{2}{*}{ G.15 } & 1.24 & 0.92 & 1.12 & 0.74 & 4.44 & 2.58 & 4.46 & 2.88 \\
\hline & $b 1$ & $b 2$ & $b 3$ & $b 4$ & $b 5$ & $b 6$ & $b 7$ & $b 8$ \\
\hline$b$ values & 0.098 & 0.072 & 0.066 & 0.041 & 0.279 & 0.209 & 0.286 & 0.219 \\
\hline$t(b=0)$ & $9.42^{* * *}$ & $9.17^{* * *}$ & $3.07^{* *}$ & $2.80^{*}$ & $9.94^{* * *}$ & $8.39^{* * *}$ & $13.34^{* * *}$ & $11.30^{* * *}$ \\
\hline
\end{tabular}

Table 3 shows the average of extra bristles per individual along 15 generations of selection, in the four lines from STD and INV populations. The regression coefficients of mean extra bristles against generation number were significant in all cases and therefore the response to selection was significant.

Males and females exhibit sexual dimorphism for bristle number although following the same pattern (Table 3); hence, only one sex is taken into account, usually the females. The response to selection was analysed by comparing the female regression slopes b1, b3, b5 and b7 following Sokal \& Rohlf (1981). The four slopes were significantly $(P<0.001)$ different (Table 4) but by separating the analysis of variance into its components, one can see that the differences between b1 and b3 (STD-1 and STD-2 lines) and between b5 and b7 (INV-1 and INV-2 lines) are not significant. The only significant difference $(P<0.001)$ is that between bS (corresponding to STD lines pooled) and bI (corresponding to INV lines pooled) (Table 4). That is, lines derived from the INV population reached averages of extra bristles per female that were significantly different (about four times higher) than lines
Table 4 Analysis of variance for the differences among the regression coefficients $(b s)$ of the four selected lines

\begin{tabular}{lllll}
\hline Source of variation & d.f. SS & \multicolumn{1}{l}{$M S$} & \multicolumn{1}{l}{$F$} \\
\hline Among $b \mathrm{~s}(b 1, b 3, b 5, b 7)$ & 3 & 13.8512 & 4.6171 & $29.807^{* * *}$ \\
Between $b 1 \& b 3$ & 1 & 0.1670 & 0.1670 & 1.078 \\
Between $b 5 \&$ \& $b 7$ & 1 & 0.0102 & 0.0101 & 0.065 \\
Between $b$ S \& $b \mathrm{I}$ & 1 & 13.6740 & 13.6740 & $88.276^{* * *}$ \\
Within $b$ (error) & 56 & 8.675 & 0.155 & \\
\hline
\end{tabular}

$* * *=P<0.001$.

from the STD population. The response to selection for increasing the number of extra bristles is very much faster in lines with the $\operatorname{In}(3 R) C$ than in lines with the standard arrangement.

Chromosomal constitution and the number of extra bristles per female from STD-1 and INV-1 in generation 15 are shown in Table 5 . The frequency of $\operatorname{In}(3 R) C$ increased from 5 per cent at G.0 to 16 per cent at G.15 in STD-1 through selection for bristles, showing Hardy-Weinberg proportions $\left(\chi_{1}^{2}=0.087\right)$ in 
Table 5 Females from the fifteenth generation in STD-1 and INV-1 lines showing their chromosomic constitution and number of extra bristles. Average of extra bristles per female

\begin{tabular}{|c|c|c|c|c|c|c|}
\hline \multirow{2}{*}{$\begin{array}{l}\text { Number of } \\
\text { extra bristles }\end{array}$} & \multicolumn{3}{|c|}{ Line STD-1 } & \multicolumn{3}{|c|}{ Line INV-1 } \\
\hline & $\mathrm{St} / \mathrm{St}$ & St $/ 3 R C$ & $3 \mathrm{RC} / 3 \mathrm{RC}$ & $\mathrm{St} / \mathrm{St}$ & $\mathrm{St} / 3 \mathrm{RC}$ & $3 \mathrm{RC} / 3 \mathrm{RC}$ \\
\hline 0 & 14 & & & & & \\
\hline 1 & 17 & 1 & & & 1 & \\
\hline 2 & 4 & 13 & & 4 & & \\
\hline 3 & & & 1 & 3 & 5 & \\
\hline 4 & & & & 1 & 6 & 4 \\
\hline 5 & & & & 1 & 12 & 3 \\
\hline 6 & & & & & 4 & 1 \\
\hline 7 & & & & & & 1 \\
\hline 10 & & & & & 1 & \\
\hline Totals & 35 & 14 & 1 & 9 & 29 & 9 \\
\hline Average of EB per female & 0.71 & 1.93 & 3 & 2.89 & 4.62 & 4.89 \\
\hline
\end{tabular}

the fifteenth generation. On the contrary, in INV-1 the frequency of $\operatorname{In}(3 \mathrm{R}) \mathrm{C}$ decreased from 71 per cent at G.0 to 50 per cent at G.15, although it too was in Hardy-Weinberg equilibrium $\left(\chi_{1}^{2}=2.57\right)$.

By testing the correlation between the number of chromosomes with $\operatorname{In}(3 \mathrm{R}) \mathrm{C}$ (none in St/St, one in St/ $3 R C$ and two in $3 R C / 3 R C$ ) and the number of extra bristles in each female, a highly significant individual correlation was revealed in females from STD-1 line $(r=0.731 ; P<0.001)$ and from INV-1 line $(r=0.407$; $P<0.01)$. Even if the correlation is established in all females without taking into account what line the females are from, the correlation is still highly significant $(r=0.671 ; P<0.001)$. The average number of extra bristles is about twice in females with $\operatorname{In}(3 R) C$ than in those without this inversion.

\section{Discussion}

Populations INV and STD were created by selecting lines only with respect to their frequency of $\operatorname{In}(3 R) C$ and differed significantly in the frequency of that inversion. It was shown that the frequency of individuals with extra bristles in those populations and in STD $\times I N V$ and INV $\times$ STD populations was correlated with their $\operatorname{In}(3 R) C$ frequency (Table 1$)$. The frequency of $\operatorname{In}(3 R) C$ changed slowly over the six generations scored without artificial selection in both the STD and INV populations (Table 2), and although frequencies increased in STD and decreased in INV, differences in the frequency of $\operatorname{In}(3 R) C$ and in the frequency of individuals with extra bristles persisted between the two.

In Asturian populations, $\operatorname{In}(3 \mathrm{R}) \mathrm{C}$ is correlated with dorsocentral and scutellar bristles (García-Vázquez et al., 1989) and by selecting for increasing bristle number, the frequency of $\operatorname{In}(3 \mathrm{R}) \mathrm{C}$ also increased (García-Vázquez \& Sánchez-Refusta, 1989). In the present work, selection for a higher frequency of $\operatorname{In}(3 \mathrm{R}) \mathrm{C}$ brought, as a consequence, a higher frequency of extra bristles. Again there is a positive correlation between $\operatorname{In}(3 R) C$ frequency and extra bristles in laboratory populations. García-Vázquez \& SánchezRefusta (1989) explained the correlation between the two characters by postulating the presence of genetic factors determining extra bristles on Asturian $\operatorname{In}(3 R) C$ and the present results are in agreement with this.

As expected, the response to selection for increasing bristle number was much more effective in lines with a high $\operatorname{In}(3 R) C$ frequency than in the standard ones (Tables 3-5) and, in addition, the correlation between $\operatorname{In}(3 \mathrm{R}) \mathrm{C}$ and bristles is shown to occur at the individual level (Table 5).

The different response to selection according to the frequency of $\operatorname{In}(3 \mathrm{R}) \mathrm{C}$, and the individual correlation between $\operatorname{In}(3 \mathrm{R}) \mathrm{C}$ and bristle number, prove again that some genetic factors involved in the increase in bristle number are included in the inversion. Although all the three main chromosomes contribute to increased bristle number, chromosome 3 makes the highest contribution by increasing chaetogen production in dorsocentral and scutellar areas (Rubio \& Albornoz, 1982; Albornoz \& Rubio, 1986; García-Vázquez \& Rubio, 1988).

Following on from the usual explanation for the persistence of inversions in natural populations (e.g. Fontdevila et al., 1983), In(3R)C in Asturian populations could be a co-adapted set of genes which has captured allelic variants of bristle polygenes that determine the increased chaetogen amount (García-Vázquez 
and Sánchez-Refusta, 1989). This explains why, in the two lines, the best response to selection came from the INV population. Here, a high frequency of $\operatorname{In}(3 R) C$ is maintained and with many alleles producing chaetogen. In the lines derived from the STD population the response to selection was slower but the bristle number and the $\operatorname{In}(3 \mathrm{R}) \mathrm{C}$ frequency increased together.

Alahiotis et al. (1977) and Inoué (1979) found that the frequency of inversions decreased quickly in lines of Drosophila kept in laboratory conditions as we found in the INV line without artificial selection (Table 2). A regression of inversion percentage against generation for the INV line yields a slope of -1.811 $(P<0.01)$, whereas that for the STD line is not significant. However, García-Vázquez \& Sánchez-Refusta (1989) found that the frequency of $\operatorname{In}(3 R) C$ heterozygotes increased in lines selected for extra bristles, reaching values around $10-15$ per cent.

In the present work, after 15 generations of selection for extra bristles, $\operatorname{In}(3 \mathrm{R}) \mathrm{C}$ frequency increased from 5 to 16 per cent in the STD-1 line and, although it decreased in the INV-1 line, was maintained at a higher level (50 per cent) (Table 5). The frequency of $\operatorname{In}(3 R) C$ did not differ significantly from Hardy-Weinberg equilibrium in the two STD-1 and INV-1 lines with no excess of heterozygotes. Therefore, bristle selection and not heterokaryotype advantage can be in this case the main force behind an increase or can maintain the frequency of $\operatorname{In}(3 R) C$ at a high level.

The existence within $\operatorname{In}(3 \mathrm{R}) \mathrm{C}$ of gene factors for bristle number increase is probably not an adequate explanation for the persistence in high frequency of this inversion in natural Asturian populations. Genes directly concerned with fitness could also be carried by the $\operatorname{In}(3 \mathrm{R}) \mathrm{C}$, and so contribute to its persistence at a high level in natural populations.

\section{References}

AFONSO, J. M., HERNANDEZ, M., PADRON, G. AND GONZALEZ, A. M. 1985. Gametic non-random associations in north-west African populations of Drosophila melanogaster. Genetica, 64, 3-11.

ALAHIOTIS, S., ZACHAROPOULOU, A. AND PELECANOS, M. 1977. The effect of two ecological factors upon the inversion fre- quencies in D. melanogaster. Dros. Inf. Serv., 52, 106-108.

ALBORNOZ, J. AND RUBIO, J. 1986. An interpretation of some bristle pattern modifications caused by directional selection in D. melanogaster. Experientia, 42, 846-848.

BARNES, P. T. 1983. Balancing selection, inversion polymorphism and adaptation in DDT-resistant populations of Drosophila melanogaster. Genetics, 105, 87-104.

FontDeVIla, A., ZAPATA, C., ALVAREZ, G., SANCHEZ, L., MENDEZ, J. AND ENRIQUEZ, I. 1983. Genetic coadaptation in the chromosomal polymorphism of $D$. subobscura. I. Seasonal changes of gametic disequilibrium in a natural population. Genetics, 105, 935-955.

GARCIA-VAZZUEZ, E. AND RUBIO, J. 1988. Chromosomal analysis of selected lines of Drosophila melanogaster with a new level of bristle canalization. Génét. Sél. Evol., 20, 75-86.

GaRCIA-VAZZUEZ, E. AND SANCHEZ-REFUSTA, F. 1989. Chromosomal polymorphism and extra bristles of Drosophila melanogaster: joint variation under selection in isofemale lines. Genetica, 78, 91-96.

GARCIA-VAZZUEZ, E., SANCHEZ-REFUSTA, F. AND RUBIO, J. 1989. Chromosome inversions and frequency of extra bristles in natural populations of Drosophila melanogaster. J. Hered., 80, 193-196.

INOUE, x. 1979. The fate of polymorphic inversions of $D$. melanogaster transferred to laboratory conditions. Jap. J. Genetics, 54, 83-96.

LAURIE-AHLbERG, C. C. AND MERRELl, D. J. 1979. Aldehyde oxidase allozymes, inversions and DDT resistance in some laboratory populations of Drosophila melanogaster. Evolution, 33, 342-349.

LEFEVRE, G., JR. 1976. A photographic representation and interpretation of the polytene chromosomes of Drosophila melanogaster salivary glands. In: Ashburner, M. and Novitski, E. (eds), The Genetics and Biology of Drosophila. Academic Press, London, New York, Vol. 1a, pp. 32-64.

LEVINE, L. AND SCHWARTZ, N. M. 1970. Laboratory Exercises in Genetics. The C. V. Mosby Company, Saint Louis.

RUBIO, J. AND ALBORNoz, J. 1982. Supresión y adición de macroquetas dorsocentrales y escutelares en Drosophila melanogaster. Rev. Cien. Ex., Fis. y Nat., 76, 773-802.

SHELDON, B. L. AND MILTON, M. K. 1972. Studies on the scutellar bristles of D. melanogaster. II. Genetics, 71, 567-595.

SOKAL, R. R. AND ROHLF, F. J. 1981. Biometry, W. H. Freeman and Company, San Francisco.

WATANABE, T. K. AND YAMAZAKI, T. 1976. Evidence for coadaptation: negative correlation between lethal genes and polymorphic inversions in Drosophila melanogaster. Genetics, 82, 697-702. 